\title{
Toxigenic algae and associated phycotoxins in two coastal embayments in the Ebro Delta (NW Mediterranean)
}

\author{
Julia A. Busch ${ }^{a, b, *}$, Karl B. Andree ${ }^{c}$, Jorge Diogène ${ }^{c}$, Margarita Fernández-Tejedor ${ }^{c}$, \\ Kerstin Toebe $^{\mathrm{b}}$, Uwe John ${ }^{\mathrm{b}}$, Bernd Krock ${ }^{\mathrm{b}}$, Urban Tillmann ${ }^{\mathrm{b}}$, Allan D. Cembella ${ }^{\mathrm{b}}$ \\ ${ }^{a}$ University of Oldenburg, Institute for Chemistry and Biology of the Marine Environment, 26111 Oldenburg, Germany \\ ${ }^{\mathrm{b}}$ Alfred-Wegener-Institut, Helmholtz-Zentrum für Polar- und Meeresforschung, 27570 Bremerhaven, Germany \\ ' IRTA, Ctra Poble Nou km 5,5, 43540 Sant Carles de la Rapita, Tarragona, Spain
}

\section{A R T I C L E I N F O}

\section{Article history:}

Received 21 August 2015

Received in revised form 24 February 2016

Accepted 29 February 2016

\section{Keywords:}

HAB surveillance

Semi-enclosed embayment

Light microscopy

Quantitative PCR

LC-MS/MS

LSU rDNA

\begin{abstract}
A B S T R A C T
Harmful Algal Bloom (HAB) surveillance is complicated by high diversity of species and associated phycotoxins. Such species-level information on taxonomic affiliations and on cell abundance and toxin content is, however, crucial for effective monitoring, especially of aquaculture and fisheries areas. The aim addressed in this study was to determine putative HAB taxa and related phycotoxins in plankton from aquaculture sites in the Ebro Delta, NW Mediterranean. The comparative geographical distribution of potentially harmful plankton taxa was established by weekly field sampling throughout the water column during late spring-early summer over two years at key stations in Alfacs and Fangar embayments within the Ebro Delta. Core results included not only confirmed identification of HAB taxa that are common for the time period and geographical area, but also provided evidence of potentially new taxa. At least 25 HAB taxa were identified to species level, and an additional six genera were confirmed, by morphological criteria under light microscopy and/or by molecular genetics approaches involving qPCR and next generation DNA pyrosequencing. In particular, new insights were gained by the inclusion of molecular techniques, which focused attention on the HAB genera Alexandrium, Karlodinium, and Pseudo-nitzschia. Noteworthy is the discovery of Azadinium sp., a potentially new HAB species for this area, and Gymnodinium catenatum or Gymnodinium impudicum by means of light microscopy. In addition, significant amounts of the neurotoxin domoic acid (DA) were found for the first time in phytoplankton samples in the Ebro Delta. While the presence of the known DA-producing diatom genus Pseudo-nitzschia was confirmed in corresponding samples, the maximal toxin concentration did not coincide with highest cell abundances of the genus and the responsible species could not be identified. Combined findings of microscopic and molecular detection approaches underline the need for a synoptic strategy for HAB monitoring, which integrates the respective advantages and compensates for limitations of individual methods.
\end{abstract}

(c) 2016 Elsevier B.V. All rights reserved.

\section{Introduction}

Species-specific information is crucial for surveillance of harmful algal blooms (HABs), a proposition recently defended in a comprehensive review (see Pitcher, 2012 and article therein). Adequate responses to such events are complicated by a large

\footnotetext{
* Correspondence to: University of Oldenburg, Carl-von-Ossietzky-Straße 9-11, 26111 Oldenburg, Germany. Tel.: +49 44219940.

E-mail addresses: julia.busch@uni-oldenburg.de (J.A. Busch), karl.andree@irta.cat (K.B. Andree), jorge.diogene@irta.cat (J. Diogène), margarita.fernandez@irta.cat (M. Fernández-Tejedor), kerstin.toebe@awi.de (K. Toebe), uwe.john@awi.de (U. John), bernd.krock@awi.de (B. Krock), urban.tillmann@awi.de (U. Tillmann), allan.cembella@awi.de (A.D. Cembella).
}

diversity of harmful species, especially as algal communities known to be delineated within geographic areas are subject to changes. Both records of harmful algal blooms and toxigenic species are apparently increasing worldwide-a phenomenon linked to the Global Spreading Hypothesis (Hallegraeff, 1993). Reasons for this apparent expansion may include not only a naturally increasing scientific and cultural awareness about HABs, and discovery and description of new species, e.g., of the genus Azadinium as novel toxin producer Tillmann et al. (2009), but also the actual introduction of novel taxa and associated phycotoxins to new areas. Range expansion of HAB species is enhanced by multiple vectors, amongst these ballast water discharge from ship traffic and inadvertent introduction via transfer of aquaculture stocks. 
Up-to-date description of species biogeography is important for both the interpretation of distributional patterns of taxa from time-series data (of which few exist), as well as formulation of management actions to react to or prevent adverse effects on human health, especially in coastal zones linked to tourism and aquaculture activities. As such, two embayments of the Ebro Delta undergo long-term routine monitoring to ensure seafood safety for the major Catalonian shellfish cultivation zones. In Alfacs and Fangar bays, the Mediterranean mussel Mytilus galloprovincialis is cultured on wooden fixed constructions (Ramón et al., 2007). Due to harvest closures dictated by the detection of toxins above the regulatory limit in shellfish flesh or the mere presence of toxic species above critical cell abundances, the aquaculture industry faces financial penalties. High levels of paralytic shellfish poisoning (PSP) toxins, produced by the dinoflagellate Alexandrium minutum, as well as of diarrhetic shellfish poisoning (DSP) toxins, attributed to members of the dinoflagellate genus Dinophysis (FernándezTejedor et al., 2008, 2010) are the major reasons for these biotoxin closures. Other dinoflagellates known to produce lipophilic phycotoxins have also been detected in both bays, including Protoceratium reticulatum, a possible source of yessotoxins in Ebro Delta shellfish (Diogène et al., 2008), Lingulodinium polyedrum and Prorocentrum lima. In addition, high biomass blooms dominated by the ichthyotoxic dinoflagellates Karlodinium armiger and Karlodinium veneficum (formerly known collectively as Gyrodinium corsicum in this area, compare Garcés et al., 2006) has led to severe fish-kills in Alfacs Bay and land-based aquaculture facilities (Fernández-Tejedor et al., 2007). In Fangar Bay, no high cell abundances were detected until June 2010 (Busch et al., 2012; Fernández-Tejedor et al., 2010; Llebot et al., 2011). The putative fish-killing agents known as karlotoxins have been identified for $K$. veneficum (Place et al., 2012) but not for K. armiger.

Since the inclusion of monitoring for the phycotoxin domoic acid (DA) in routine shellfish toxin sampling in 2001, DA was not detected in the area until 2008-2011, during which DA was found in several harvested mollusc species from production sites along the Catalan coast, including the Ebro embayments (Giménez Papiol et al., 2013). In a few samples, DA even exceeded regulatory limits of $20 \mathrm{mg} \mathrm{kg}^{-1}$ shellfish flesh. As yet, the origin of the toxin has not been attributed to a known producer species, despite high cell abundances of the diatom genus Pseudo-nitzschia. Nor could the presence of DA in shellfish be clearly related to high cell abundances of this diatom, as the toxin was not detected in Pseudo-nitzschia-rich plankton samples (or only at low levels of maximum $0.05 \mathrm{pg} \mathrm{cell}^{-1}$; Fernández-Tejedor, pers. comm.). During the past 50 years, as abundances of this diatom have been increasing in the Ebro Delta area (Fernández-Tejedor et al., 2010), knowledge on its distribution and toxin production is becoming increasingly important.

Besides monitoring efforts, detailed targeted studies of cell morphology by electron microscopy, and molecular diversity with genetic probes, have been conducted for a few HAB taxa in the Ebro Delta. For example, such techniques aided in the discrimination of Pseudo-nitzschia populations and cultured isolates at the species level over time (Andree et al., 2011; Quijano-Scheggia et al., 2008). Nevertheless, analyses of field samples were based mainly on integrated samples throughout the water column or on a crude distinction between surface and bottom samples. As species of Pseudo-nitzschia are known to form thin layers of concentrated cells in the water column (Rines et al., 2002) more detailed insights can be expected by a depth resolved sampling method. Furthermore, molecular screening in this region has only been conducted for specific target genera, and therefore may not include newly introduced or overlooked taxa that are not clearly distinguishable by light microscopy.

Accordingly, the overarching objectives of the current study were to contribute to defining and describing the distribution of harmful planktonic algae and toxins, as well as applying and testing traditional and new observational methods. These objectives were achieved by identification and assignment of HAB taxa and toxins in corresponding samples over the entire water column and with high depth resolution $(0.5 \mathrm{~m})$ at two key stations in Alfacs and Fangar bays in the Ebro Delta. Besides novel findings on species of HAB genera known to the area, in particular on Karlodinium and Pseudo-nitzschia species, emphasis was set upon the identification of cryptic (or previously absent) but potentially harmful emerging species. A number of alternative approaches for surveillance of $\mathrm{HAB}$ events were integrated to confirm the presence of HAB taxa that are not routinely resolved by light microscopy or targeted molecular methods.

\section{Material and methods}

\subsection{Location and field sampling of the study sites}

Water samples for all analyses were collected during weekly sampling excursions $(n=30)$ from May to July in 2010 and 2011 at two key stations within the Ebro Delta system of the NW Mediterranean (Fig. 1). In both embayments, Alfacs $\left(40.620083^{\circ} \mathrm{N}\right.$, $\left.0.658167^{\circ} \mathrm{E}\right)$ and Fangar $\left(40.778767^{\circ} \mathrm{N}, 0.749233^{\circ} \mathrm{E}\right)$ bays, the water column was sampled from surface to bottom at $0.5 \mathrm{~m}$ intervals for taxon and toxin analysis, with a submersible pumping system (weighted hose) from a small vessel. Sub-samples $(100 \mathrm{~mL})$ were collected directly into screw-cap plastic vials and fixed with neutral-buffered Lugol's iodine solution for identification and enumeration of phytoplankton by light microscopy. Water for high-throughput DNA sequencing was collected in $1 \mathrm{~L}$ plastic bottles, whereas samples for polymerase chain reaction (PCR) analysis were collected in $50 \mathrm{~mL}$ plastic centrifuge tubes, and immediately fixed with neutral Lugol's solution. Plankton for toxin analysis was obtained directly from the on-board pumping system; water volume (1 L in 2010 and $2 \mathrm{~L}$ in 2011) was gently transferred to a filter tower sealed at one end with $10 \mu \mathrm{m}$ Nitex gauze mesh. The retentate on the gauze was re-suspended and washed off the filter with $0.2 \mu \mathrm{m}$-filtered seawater and collected in a $50 \mathrm{~mL}$ plastic centrifuge tube. All samples on board were stored and transported at $<10^{\circ} \mathrm{C}$ and under dark conditions and then processed immediately in the laboratory or archived within several hours for future processing.

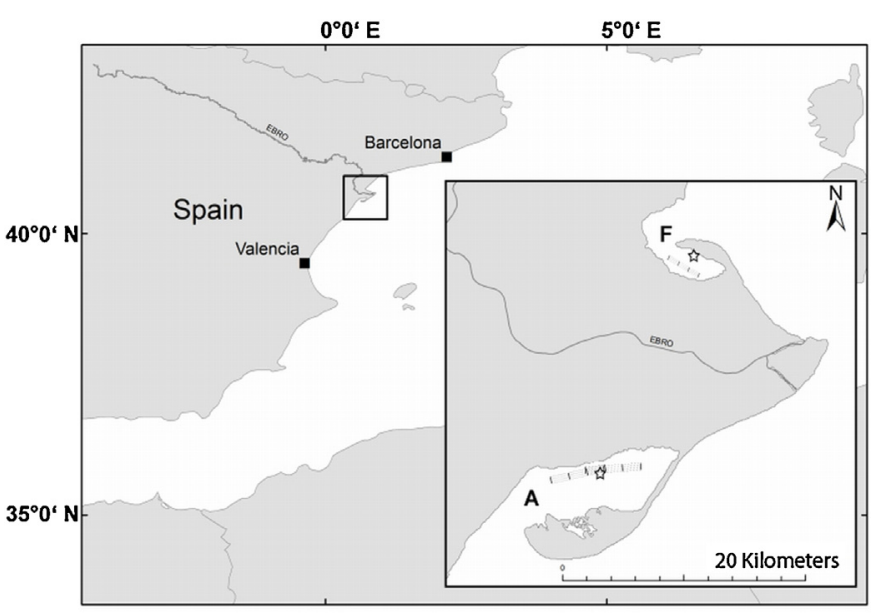

Fig. 1. Location of the study sites, Alfacs Bay (A) and Fangar Bay (F), in the Ebro Delta on the Catalan coast (NW Mediterranean). Key sampling stations in both embayments are marked with a star. Shellfish aquaculture of the Mediterranean mussel Mytilus galloprovincialis is conducted on fixed constructions in both bays (dashed lines). 


\subsection{Identification and characterization of harmful phytoplankton}

\subsubsection{Identification and enumeration of $H A B$ taxa by inverted light microscopy}

Taxonomic analysis of field plankton samples for $2010(n=156)$ and $2011(n=136)$ was conducted according to the Utermöhl (1931) inverted microscope method, based on the European Standard (CEN, 2006) applied to a $50 \mathrm{~mL}$ sub-sample. Most samples were analyzed with a Zeiss Axiovert 40 or Axiovert 35 microscope (Zeiss, Jena, Germany), but a few were examined with a Nikon Eclipse TE2000 S (Tokyo, Japan) or Leitz Labovert (Leitz, Wetzlar, Germany) inverted microscope. Members of the microplankton community were identified and enumerated at species or genus level when possible. Identification of species was mainly based on standard taxonomic references (Hoppenrath et al., 2009; Tomas, 1997), and the IOC-UNESCO Taxonomic Reference List of Harmful Micro Algae (Moestrup et al., 2009 onwards).

\subsubsection{Molecular diversity of $H A B$ taxa determined by amplicon pyrosequencing}

Molecular diversity analysis was based upon pyrosequencing of amplicons generated from the $28 \mathrm{~S}$ large-subunit (LSU) rDNA. Analysis by pyrosequencing technology (Roche 454) and DNAbased molecular markers was conducted upon a $300 \mathrm{~mL}$ subsample filtered through a $0.2 \mu \mathrm{m}$ pore-size polycarbonate filter (Millipore, Darmstadt, Germany). The filter was then folded and stored in a $1.5 \mathrm{~mL}$ safe-lock tube (Eppendorf, Hamburg, Germany) at $-80{ }^{\circ} \mathrm{C}$ until further analysis. Three samples from Fangar Bay, collected from the upper and lower water column at the end of the 2010 study, were selected for this analysis by referring to plankton composition determined by light microscopy.

For DNA extraction, the filter content was rinsed off with preheated $\left(65^{\circ} \mathrm{C}\right)$ AP1 buffer (DNeasy; Qiagen, Hamburg, Germany) by pipetting, and then vortex-mixed for $30 \mathrm{~s}$. DNA was extracted with a mini-shredder kit (Qiagen, Hamburg, Germany) as follows: $200 \mu \mathrm{L}$ of acid-washed glass beads ( $80-200 \mu \mathrm{m})$ (Sigma-Aldrich, Munich, Germany) were added to the cells in $400 \mu \mathrm{L}$ AP1 buffer. The mixture and glass beads were incubated for $10 \mathrm{~min}$ at $65{ }^{\circ} \mathrm{C}$ and vortexed for $15 \mathrm{~s}$ at $5 \mathrm{~min}$ intervals. Subsequently, cell lysis was completed by two $20 \mathrm{~s}$ extractions at position 6.5 in a TissueLyser (Qiagen, Hamburg, Germany). Afterwards, $4 \mu \mathrm{L}$ RNase $\left(100 \mathrm{mg} \mathrm{mL}^{-1}\right)$ was added and the mixture was incubated at $65{ }^{\circ} \mathrm{C}$ for $15 \mathrm{~min}$, with vortexing for $15 \mathrm{~s}$ every $5 \mathrm{~min}$. After adding $130 \mu \mathrm{L}$ AP2 buffer, the tube was kept on ice for $5 \mathrm{~min}$ and then centrifuged at $12,000 \mathrm{~g}$ for $5 \mathrm{~min}$. The supernatant was then transferred to a QIAshredder ${ }^{\mathbb{R}}$ mini-spin column and centrifuged at $12,000 \mathrm{~g}$ for $2 \mathrm{~min}$. The supernatant was transferred into a new $2 \mathrm{~mL}$ tube and $750 \mu \mathrm{L}$ AP3 buffer was added. This mixture $(650 \mu \mathrm{L})$ was added to a DNeasy ${ }^{\mathbb{R}}$ spin-column and centrifuged at $5900 \mathrm{~g}$ for $1 \mathrm{~min}$. After discarding the filtrate, the previous step was repeated. The DNA was washed by adding $500 \mu \mathrm{L}$ AW buffer (DNeasy; Qiagen, Hamburg, Germany) to the column; this mixture was incubated for $30 \mathrm{~s}$ and subsequently centrifuged at $5900 \mathrm{~g}$ for $1 \mathrm{~min}$. This step was repeated with $96 \%$ ethanol. The column was dried by centrifugation at $12,000 \mathrm{~g}$ for 2 min to remove remaining ethanol that would reduce the purity and yield of the elution step. The DNA was eluted into a clean $1.5 \mathrm{~mL}$ tube by adding $50 \mu \mathrm{L} \mathrm{AE}$ buffer (DNeasy; Qiagen, Hamburg Germany) to the center of the membrane and incubating for $5 \mathrm{~min}$ at room temperature, followed by centrifugation at $5900 \mathrm{~g}$ for $1 \mathrm{~min}$.

2.2.2.1. PCR template amplification. Universal eukaryotic primers (Scholin et al., 1994) targeting the hypervariable D1-D2 domain of LSU rDNA were used to generate fusion primers (454 sequence adaptor A or B; key sequence; MID and D1R-F or D2C-R) for FastStart High Fidelity PCR (Roche, Mannheim, Germany). The reactions were executed in $50 \mu \mathrm{L}$ aliquots containing $1 \times$ High Fidelity buffer, $5 \times$ High Fidelity Taq polymerase, $200 \mu \mathrm{M}$ dNTPs, $0.2 \mu \mathrm{M}$ final concentration of each primer, and $10 \mathrm{ng}$ purified community DNA. The thermal cycling was set up with a denaturation step at $94{ }^{\circ} \mathrm{C}$ for 2 min followed by 30 cycles each of $94{ }^{\circ} \mathrm{C}$ for $30 \mathrm{~s}, 55^{\circ} \mathrm{C}$ for $30 \mathrm{~s}, 72{ }^{\circ} \mathrm{C}$ for $2 \mathrm{~min}$, and finally by a last elongation step at $72{ }^{\circ} \mathrm{C}$ for $10 \mathrm{~min}$.

2.2.2.2. Amplicon preparation and sequencing. The PCR products were separated in $1 \%$ agarose gel at $80 \mathrm{~V}$ for $1 \mathrm{~h}$. Band components larger than 700-900 bp were excised and purified with a MinElute gel extraction kit (Qiagen, Hamburg, Germany). Contaminants and small fragments were removed with the Ampure Bead PCR purification system (Invitrogen, Karlsruhe, Germany) following the protocol for small fragment removal. The exact size was determined with the High Sensitivity DNA kit (Agilent, Santa Clara, USA). The 454-amplicon sequencing was carried out on a GS Junior sequencer (Roche, Mannheim, Germany) following standard protocols.

2.2.2.3. Sequencing post-processing. The associated 454 Sequencing System Software (v2.7, default parameters) was used for quality control. All sequencing reads featuring inaccurate key sequences, chimeric sequences, biased nucleotides, or unidentified nucleotides were regarded as low quality reads and were discarded. The sequencing data were demultiplexed and cleared from primer fragments (CLC genomic workbench v5.0). For investigation of contributions of different orders, genera and target species, only reads exceeding 200 bp were analyzed with MG-RAST v3 (Meyer et al., 2008) with annotation source set for LSU rDNA, with maximum $e$-value cutoff $1 e^{-5}$, minimum \% identity cutoff $97 \%$ and minimum alignment length cutoff of 100 .

The LSU sequences that matched to HAB taxa and genera, including members of Alexandrium, Karenia, Karlodinium, Azadinium, Gymnodinium, and Pseudo-nitzschia, were further examined to validate and confirm the sequence assignment. The 1874 sequence read data matrices obtained from the MG-Rast analyses were aligned together with LSU sequences of a high variety of target sequences retrieved from GenBank using the multiple sequence alignment algorithm ClustalW in MEGA6 (Tamura et al., 2013). Each alignment was refined manually. Maximum likelihood phylogenies for the target species/groups were run in MEGA6 by accessing the General Time Reversible model $(G T R+G)$ with five discrete Gamma categories. The robustness of phylogeny was tested with 1000 Bootstrap replications.

2.2.3. Determination of Pseudo-nitzschia spp. composition by $q P C R$ Cell pellets of field plankton samples $(50 \mathrm{~mL})$ were harvested by centrifugation ( $990 \mathrm{~g}$ for $25 \mathrm{~min}$, at $4{ }^{\circ} \mathrm{C}$ (in 2010) and $10^{\circ} \mathrm{C}$ (in 2011). After discarding the supernatant, undisturbed residuals were transferred to a $1.5 \mathrm{~mL}$ safe-lock tube (Eppendorf, Hamburg, Germany) and centrifugation was repeated at $13,000 \mathrm{~g}$ for $5 \mathrm{~min}$ at room temperature to consolidate the pellets. The cell pellets were stored at $-20{ }^{\circ} \mathrm{C}$ in cryo-tubes until further processing.

A total of 27 samples were selected, based upon highest cell counts of Pseudo-nitzschia spp. by light microscopy and presence of the toxin domoic acid (DA). These samples were then processed (following Andree et al., 2011; Fawley and Fawley, 2004) by targeting the species Pseudo-nitzschia arenysensis (=Pseudonitzschia delicatissima, strain Ra3), Pseudo-nitzschia brasiliana, Pseudo-nitzschia calliantha, Pseudo-nitzschia delicatissima (strain Ra2), Pseudo-nitzschia fraudulenta, Pseudo-nitzschia galaxiae, Pseudo-nitzschia multistriata, and Pseudo-nitzschia pungens. For DNA extraction, cell pellets were thawed and suspended in $200 \mu \mathrm{L}$ lysis buffer ( $1 \mathrm{M} \mathrm{NaCl}, 70 \mathrm{mM}$ Tris, $30 \mathrm{mM}$ EDTA, pH 8.0), then each was transferred to a $2 \mathrm{~mL}$ cryo-tube containing approximately $50 \mathrm{mg}$ of 
$0.5 \mathrm{~mm}$-diameter zirconium glass beads (BioSpec, Bartlesville, Oklahoma, USA). Microalgal DNA was collected by adding $25 \mu \mathrm{L}$ $10 \%$ DTAB (dodecyltrimethylammonium bromide) and $200 \mu \mathrm{L}$ chloroform to the tube. Cells were disrupted for $40 \mathrm{~s}$ with a BeadBeater-8 (BioSpec, Bartlesville, Oklahoma, USA) at maximum velocity, and then cooled on ice. Cell debris and beads were centrifuged (model 5415 D, Eppendorf, Hamburg, Germany) at $2000 \mathrm{~g}$ for $5 \mathrm{~min}$ at room temperature. Then $100 \mathrm{~mL}$ of aqueous supernatant was transferred to a new tube. Extraction of the genomic DNA continued from this supernatant using a GeneClean Kit (MP Biomedicals, LLC, LLC, Santa Ana, California, USA), following the procedure of Fawley and Fawley (2004). A hemispecific assay, containing one genus-specific $5.8 \mathrm{~S}$ primer and one species-specific ITS- 1 or ITS- 2 primer, was used for identification of taxa (Andree et al., 2011). Duplicate amplifications were performed on an ABI 7300 real-time PCR system (ABI, Carlsbad, California, USA) in $20 \mu \mathrm{L}$ volumes extended for 45 cycles with a standard two-step protocol at $94{ }^{\circ} \mathrm{C}$ for $30 \mathrm{~s}$ followed by primer annealing/extension at $65{ }^{\circ} \mathrm{C}$ for $30 \mathrm{~s}$. SYBR Green I dye in reaction mixtures was used for amplification detection and melt curve analysis. The thermal profile for melt curve determination started with an incubation of $1 \mathrm{~min}$ at $60{ }^{\circ} \mathrm{C}$ with a gradual increase in temperature $\left(1{ }^{\circ} \mathrm{C} / 15 \mathrm{~s}\right)$ to $95^{\circ} \mathrm{C}$, during which time changes in fluorescence were monitored (Andree et al., 2011).

Each species-specific hemi-nested PCR assay included a positive control (either plasmid clone or purified genomic DNA) for each species tested. Samples were only considered positive when the shape and temperature $(\mathrm{Tm})$ of the melt curve matched the control. Although curve shape may vary slightly due to point mutations within the amplified region (Andree et al., 2011), significant deviations from the control samples were considered as negative for that specific internal transcribed spacer (ITS) PCR assay.

\subsection{Identification and quantification of phycotoxins}

Samples for phycotoxin analysis (retentate from $1 \mathrm{~L}$ filtered seawater in 2010 and $2 \mathrm{~L}$ in 2011) were processed for storage on the day of collection. Plankton was condensed to cell pellets by centrifugation at $2500 \mathrm{~g}$ for $20 \mathrm{~min}$ at $4{ }^{\circ} \mathrm{C}$. The supernatant was discarded and the residues were transferred into $1.5 \mathrm{~mL}$ safelock tubes and centrifuged again for five min at 12,000g. The cell pellets were stored in cryo-vials at $-20^{\circ} \mathrm{C}$ until further processing.

For extraction of lipophilic toxins and domoic acid (DA), cell pellets were thawed, suspended in $0.5 \mathrm{~mL}$ methanol and homogenized by vortex mixing. Each sample was transferred to a FastPrep tube with $0.9 \mathrm{~g}$ lysing matrix D (Thermo Savant, Illkirch, France) to disrupt cell membranes by reciprocal shaking in a Bio101 Fast Prep instrument (Thermo Savant, Illkirch, France) for $45 \mathrm{~s}$ at maximum velocity $\left(6.5 \mathrm{~ms}^{-1}\right)$. Subsequently, cell debris was spun down by centrifugation for $15 \mathrm{~min}$ at $16,100 \mathrm{~g}$ at $4{ }^{\circ} \mathrm{C}$. The supernatants were each transferred to a spin-filter (nominal pore size $0.45 \mu \mathrm{m}$ ) (Millipore Ultrafree, Eschborn, Germany) in a safelock tube, spun for $0.5 \mathrm{~min}$ at $800 \mathrm{~g}$, and then the filtrates were transferred into glass autosampler vials and stored at $-20^{\circ} \mathrm{C}$ until further analysis.

Toxin analyses were performed on a LC-MS/MS system consisting of an Agilent model 1100 LC coupled to an API-Sciex $4000 \mathrm{Q}$ Trap triple-quadrupole mass spectrometer (AB-Sciex, Darmstadt, Germany) equipped with a TurboSpray interface, basically following a multi-toxin selected reaction monitoring (SRM) method described in Krock et al. (2008). Toxins surveyed included DA, gymnodimine (GYM), spirolide (SPX) A, spirolide B, 13-desmethylspirolide C (SPX-1), spirolide G, 13-desmethylspirolide D, spirolide C, 20-methylspirolide G, okadaic acid (OA), dinophysistoxin (DTX) 1, 2, pectenotoxin (PTX) 1, 2, pectenotoxin2-seco-acid (PTX-2sa), pectenotoxin-4, -8, -11, -12, -13, -14 and yessotoxin (YTX). All samples were analyzed for the presence of azaspiracids (AZAs) with a specific SRM method for all known AZAs, as described in Gu et al. (2013). In addition, the samples were screened for the karlotoxins listed in Place et al. (2012, Fig. 4) by LC-MS in Single Ion Monitoring (SIM) scans of the hypothesized sodium adducts. Separation of toxin analytes in $5 \mu \mathrm{L}$ sample injection volume was performed by reverse-phase chromatography on a C8 stationary phase. The analytical column $(50 \times 2 \mathrm{~mm})$ was packed with $3 \mu \mathrm{m}$ Hypersil BDS $120 \AA$ (Phenomenex, Aschaffenburg, Germany) and maintained at $20^{\circ} \mathrm{C}$. The flow rate was $0.2 \mathrm{~mL} \mathrm{~min}^{-1}$ and gradient elution was performed with two eluants, where eluant A was water and B was acetonitrile/water $(95: 5 \mathrm{v} / \mathrm{v})$, both containing $2.0 \mathrm{mM}$ ammonium formate and $50 \mathrm{mM}$ formic acid. Initial conditions were $8 \mathrm{~min}$ column equilibration with $30 \% \mathrm{~B}$, followed by a linear gradient to $100 \%$ $\mathrm{B}$ in $8 \mathrm{~min}$ and isocratic elution until $15 \mathrm{~min}$ with $100 \% \mathrm{~B}$, then returning to initial conditions until $18 \mathrm{~min}$ (total run time: $26 \mathrm{~min}$ ). Sodium adducts of karlotoxins were determined in one period (0-15) min with curtain gas: $20 \mathrm{psi}$, ion-spray voltage: $5500 \mathrm{~V}$, temperature: $550{ }^{\circ} \mathrm{C}$, nebulizer gas: 30 psi, auxiliary gas: $60 \mathrm{psi}$, interface heater: on, declustering potential: $151 \mathrm{~V}$ and entrance potential: $10 \mathrm{~V}$. SIM experiments were carried out in positive ion mode.

For extraction of hydrophilic toxins, specifically the saxitoxin and analogs associated with paralytic shellfish poisoning (PSP), the remaining cell debris was again suspended in $0.5 \mathrm{~mL}$ (in 2010) or $0.3 \mathrm{~mL}$ (in 2011) $0.03 \mathrm{M}$ acetic acid and subjected to the same FastPrep and filtration procedure as described for lipophilic toxins. Samples in glass autosampler vials were also stored at $-20^{\circ} \mathrm{C}$ until analysis of the samples. The PSP toxins were determined by reversed phase ion-pair liquid chromatography with post-column derivatization and fluorescence detection (LC-FD) as described in Krock et al. (2007).

\section{Results}

\subsection{Harmful species identified by light microscopy}

A total of 17 putative $\mathrm{HAB}$ taxa from field samples were identified to species, and seven additional taxa were assigned at the genus level, based upon morphological features observed by inverted light microscopy (Table 1 ). Morphological identification comprised regionally well-known phycotoxin-producing dinoflagellates, mainly Dinophysis acuminata, Dinophysis sacculus (Fig. 2), Lingulodinium polyedrum, Protoceratium reticulatum, Alexandrium spp., and Karlodinium spp. (Table 1); most of these species were present only in low cell numbers. Threshold alert cell abundances, as defined by the Food and Veterinary Office for the region, were exceeded in discrete samples by various taxa, including D. acuminata and D. sacculus ( $>500$ cells L $^{-1}$ ) and Karlodinium spp. ( $>200,000$ cells $\left.\mathrm{L}^{-1}\right)$. Low cell numbers $\left(<100\right.$ cells $\mathrm{L}^{-1}$ ) of a chain-forming dinoflagellate were observed and identified as a Gymnodinium species, either the toxic Gymnodinium catenatum or non-toxic Gymnodinium impudicum. In addition, potentially toxic cells of the azaspiracid-producing dinoflagellate genus Azadinium ( $<3000$ cells L ${ }^{-1}$ ) were observed by light microscopy. One specimen clearly revealed both an antapical spine (Fig. 3A) and three stalked pyrenoids visible by a starch shield, all of which were located in the episome (Fig. 3B, C).

The diatom genus Pseudo-nitzschia was heavily represented in field samples (Fig. 4), but was not readily resolved into identifiable species under the light microscope. Alert levels of this genus $\left(200,000\right.$ cells $\left.\mathrm{L}^{-1}\right)$ were frequently exceeded. 
Table 1

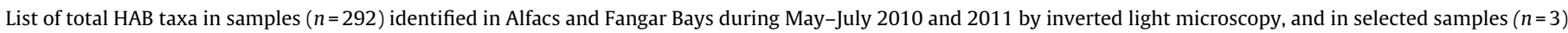

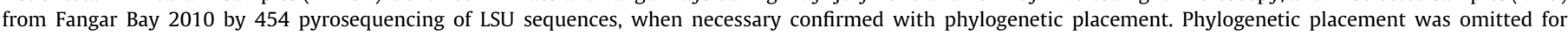

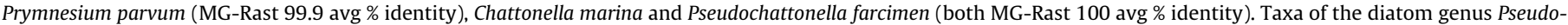

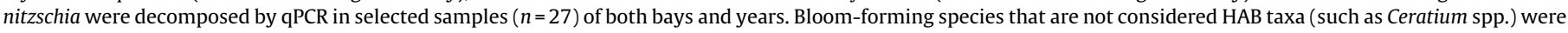

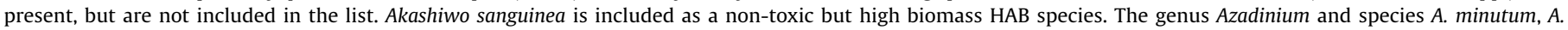
tamarense, A. ostenfeldii, K. veneficum, G. catenatum were indicated by MG-Rast, but not confirmed by phylogenetic placement of respective sequences.

\begin{tabular}{|c|c|c|c|}
\hline Class & Order & Light microscopy & $\begin{array}{l}\text { MG-RAST/Phylogenetic assignment } \\
\text { Bacillariophyceae by qPCR }\end{array}$ \\
\hline Bacillariophyceae & & Pseudo-nitzschia spp. & $\begin{array}{l}\text { P. delicatissima }(\mathrm{Ra} 2) \\
\text { P. calliantha } \\
\text { P. galaxiae } \\
\text { P. arenysensis (P. delicatissima Ra } 3)^{\mathrm{a}} \\
\text { P. delicatissima (genotype) } \\
\text { Prymnesium parvum }\end{array}$ \\
\hline \multirow[t]{7}{*}{ Dinophyceae } & Dinophysiales & $\begin{array}{l}\text { Dinophysis acuminata } \\
\text { D. norvegica } \\
\text { D. caudata } \\
\text { D. acuta } \\
\text { D. ovum } \\
\text { D. rotunda } \\
\text { D. sacculus } \\
\text { D. hastata } \\
\text { D. odiosa }\end{array}$ & $\begin{array}{l}\text { D. acuminata } \\
\text { D. norvegica } \\
\text { D. caudata }\end{array}$ \\
\hline & $\begin{array}{l}\text { Peridinales } \\
\text { Prorocentrales }\end{array}$ & $\begin{array}{l}\text { Heterocapsa spp. } \\
\text { Prorocentrum lima }\end{array}$ & Heterocapsa spp. \\
\hline & $\begin{array}{l}\text { Incertae sedis } \\
\text { Gymnodiniales }\end{array}$ & $\begin{array}{l}\text { Prorocentrum minimum }^{\mathrm{a}} \\
\text { Azadinium sp. } \\
\text { Amphidinium carterae } \\
\text { Gymnodinium catenatum or } \\
\text { G. impudicum (non-toxic) }\end{array}$ & Prorocentrum spp. \\
\hline & & $\begin{array}{l}\text { Karenia spp. } \\
\text { Karlodinium spp. }\end{array}$ & $\begin{array}{l}\text { Karenia spp. } \\
\text { Karlodinium spp. }\end{array}$ \\
\hline & Gonyaulacales & $\begin{array}{l}\text { Akashiwo sanguinea } \\
\text { Alexandrium minutum }\end{array}$ & $\begin{array}{l}\text { Takayama spp. } \\
\text { Akashiwo sanguinea }\end{array}$ \\
\hline & & & $\begin{array}{l}\text { A. fundyense } \\
\text { A. mediterraneum } \\
\text { A. pseudogonyaulax } \\
\text { A. margalefii }\end{array}$ \\
\hline & & $\begin{array}{l}\text { Lingulodinium polyedrum } \\
\text { Ostreopsis spp. } \\
\text { Protoceratium reticulatum }\end{array}$ & \\
\hline $\begin{array}{l}\text { Raphidophyceae } \\
\text { Dictyochophyceae }\end{array}$ & & Chattonella sp. ${ }^{\mathrm{b}}$ & $\begin{array}{l}\text { Chattonella marina } \\
\text { Pseudochattonella farcimen }\end{array}$ \\
\hline
\end{tabular}

a Not confirmed by IOC list of toxic species.

b Not at key stations.

\subsection{Harmful taxa detected by molecular diversity and phylogenetic analysis}

The molecular phylogenetic approach revealed a high diversity of microalgal groups, particularly dinoflagellates, containing putative HAB taxa within the Ebro Delta system. Molecular phylogeny inferred from the D1-D2 region of the LSU rDNA showed that members of the dinoflagellate families Amphidomataceae, Gonyaulacaceae, Kareniaceae, and Prorocentraceae were present. The majority of the sequences, however, could only be assigned to genus and not to species level (Table 1 ). The presence of members of the genus Alexandrium were highly supported
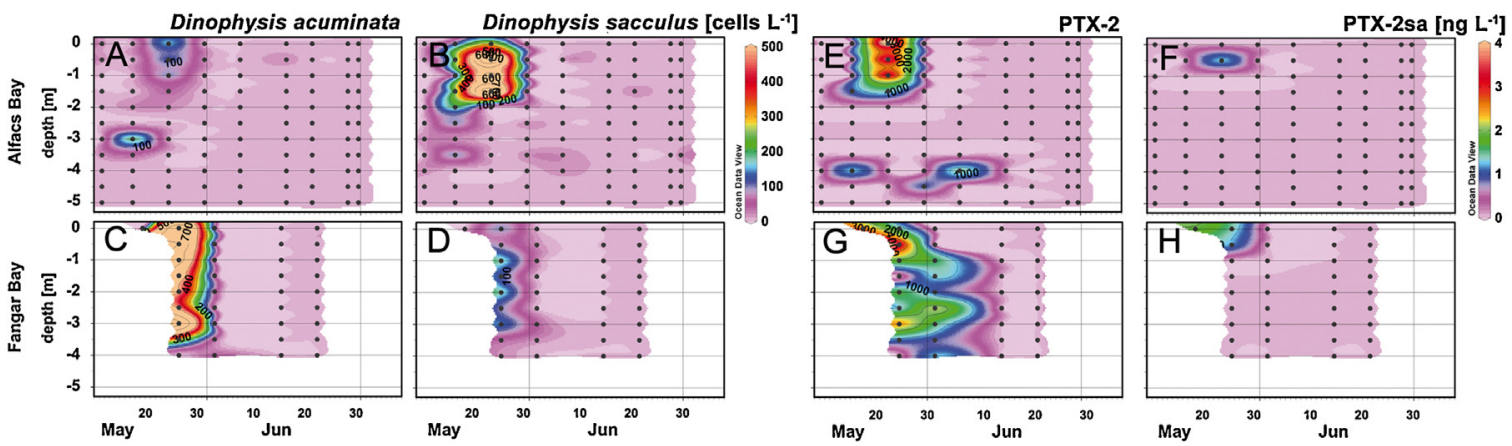

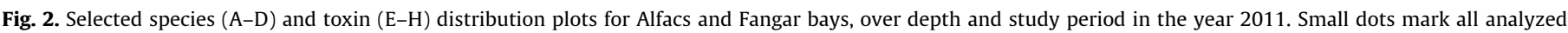

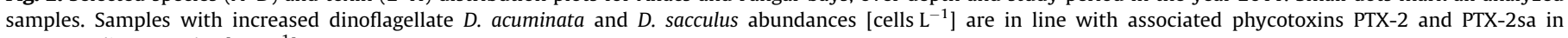
corresponding samples [ng L ${ }^{-1}$ ]. 


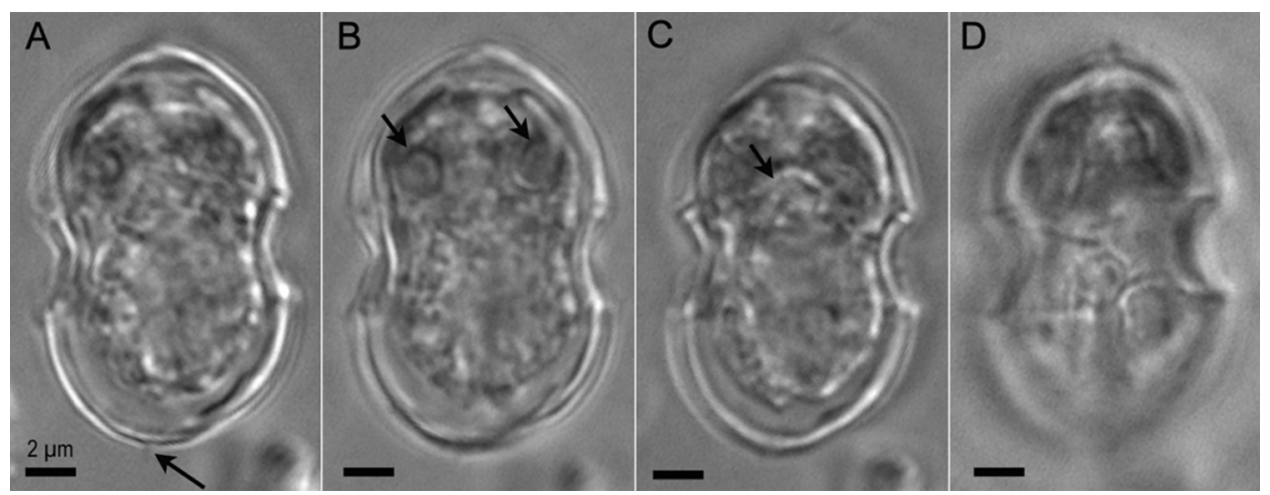

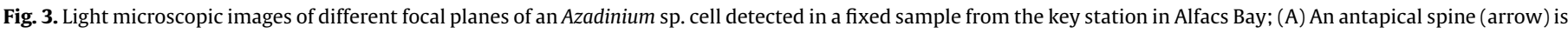
clearly visible. (B,C) Three pyrenoids (arrows) are located within the epitheca. (D) Sulcus and cingulum in ventral view.

(i.e., 99\%) by Bootstrap (BT) analysis, confirming Alexandrium fundyense, Alexandrium margalefii, Alexandrium mediterraneum, and Alexandrium pseudogonyaulax within the samples (Fig. 5). Other sequences could be assigned with high support to the dinoflagellate genera Prorocentrum, Heterocapsa, Takayama, Karenia, and Karlodinium. Sequences of the latter could be assigned to Karlodinium veneficum with only low statistical support (57\% BT), and to an additional but not assigned taxon. The assignment of other dinoflagellates to genus, e.g., to Azadinium, or to species level, e.g., Gymnodinium catenatum, were only weakly supported ( $<85 \% \mathrm{BT})$.

Among other potential HAB flagellates, the haptophyte Prymnesium parvum, the dictyochophyte Pseudochattonella farcimen and the raphidopyhte Chattonella marina were detected with LSU rDNA sequences with a percentage identity of $100 \%$ in MG-Rast.

Analysis of species diversity within the diatom genus Pseudonitzschia by targeted qPCR assays confirmed the presence of seven discrete taxa known to occur in the Ebro Delta (for strains compare Andree et al. (2011). Among these species, Pseudo-nitzschia calliantha, Pseudo-nitzschia delicatissima Ra2, and Pseudo-nitzschia galaxiae were identified as potentially toxic members of the genus (Table 1, Fig. 4). In addition, Pseudo-nitzschia arenysensis ( $P$. delicatissima Ra3) and an additional Pseudo-nitzschia taxon related to the $P$. delicatissima genotype was detected by qPCR. In 14 of 27 selected samples, none of these taxa were identified by qPCR, despite the massive presence of this genus in samples examined by light microscopy (Fig. 4). In the sample that contained the highest concentration $\left(7 \times 10^{6}\right.$ cells $\left.\mathrm{L}^{-1}\right)$ of Pseudo-nitzschia cells enumerated by light microscopy, only P. delicatissima Ra2 was identified by PCR. Four potentially toxic members of the genus, Pseudo-nitzschia brasiliana, Pseudo-nitzschia fraudulenta, Pseudo-nitzschia multistriata, and Pseudo-nitzschia pungens were not detected by qPCR in any of the 27 selected samples.

\subsection{Presence of phycotoxins}

In total, nine phycotoxins belonging to six structural groups were detected in plankton samples. In Alfacs Bay, GYM, OA, PTX-2 and PTX-2sa, PTX-11, SPX-1, and YTX were present in 2011, whereas in 2010 only GYM and SPX-1 were detected. High amounts of GYM and SPX-1 were found simultaneously in only one sample (Table 2). In Fangar Bay, SPX-1 and DA were present in both years, whereas PTX-2 and PTX-2sa were limited to samples from 2011 (Table 2). Among all detected toxins, only DA was restricted to Fangar Bay, and the four samples in which the toxin was found originated from the upper water column (Table 3, Fig. 4). Neither karlotoxins and azaspiracids, nor PSP toxins were detected in any sample throughout the study period.

\section{Discussion}

Attempts to link the presence of particular HAB taxa and known associated phycotoxins have generated new insights into their
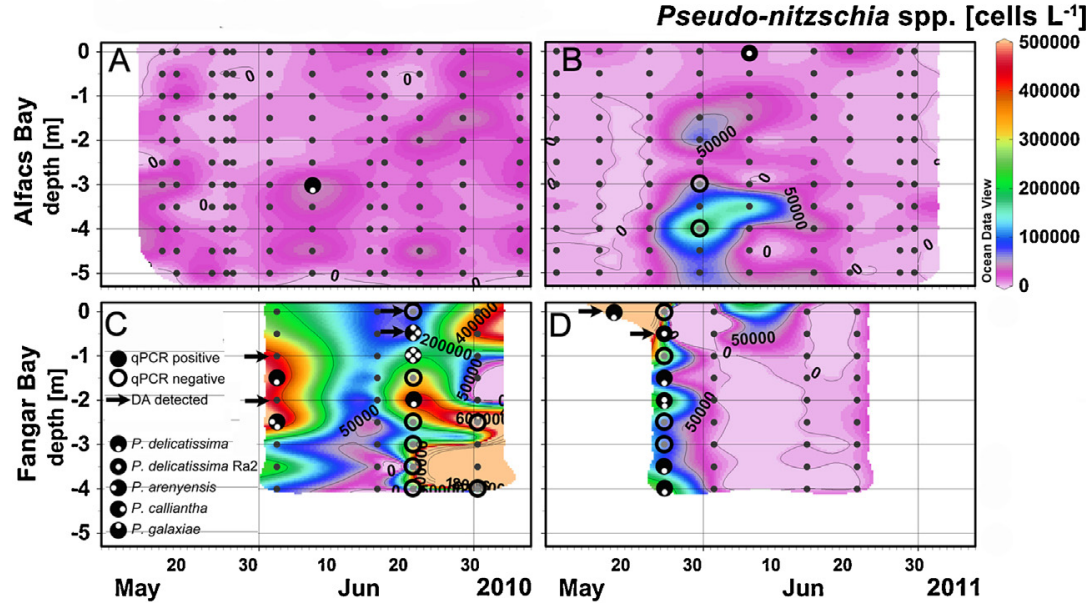

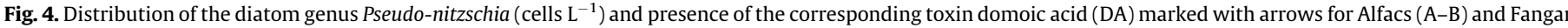

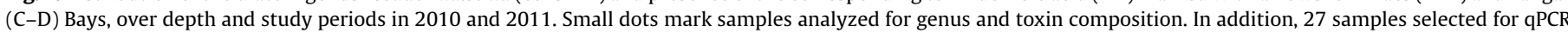

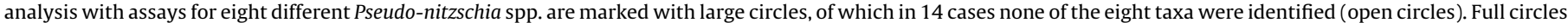

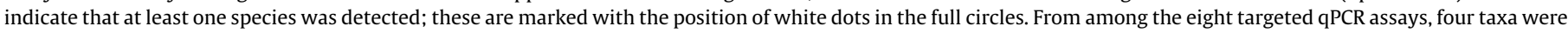
not detected: P. brasiliana, $P$. fraudulenta, $P$. multistriata, and $P$. pungens. 


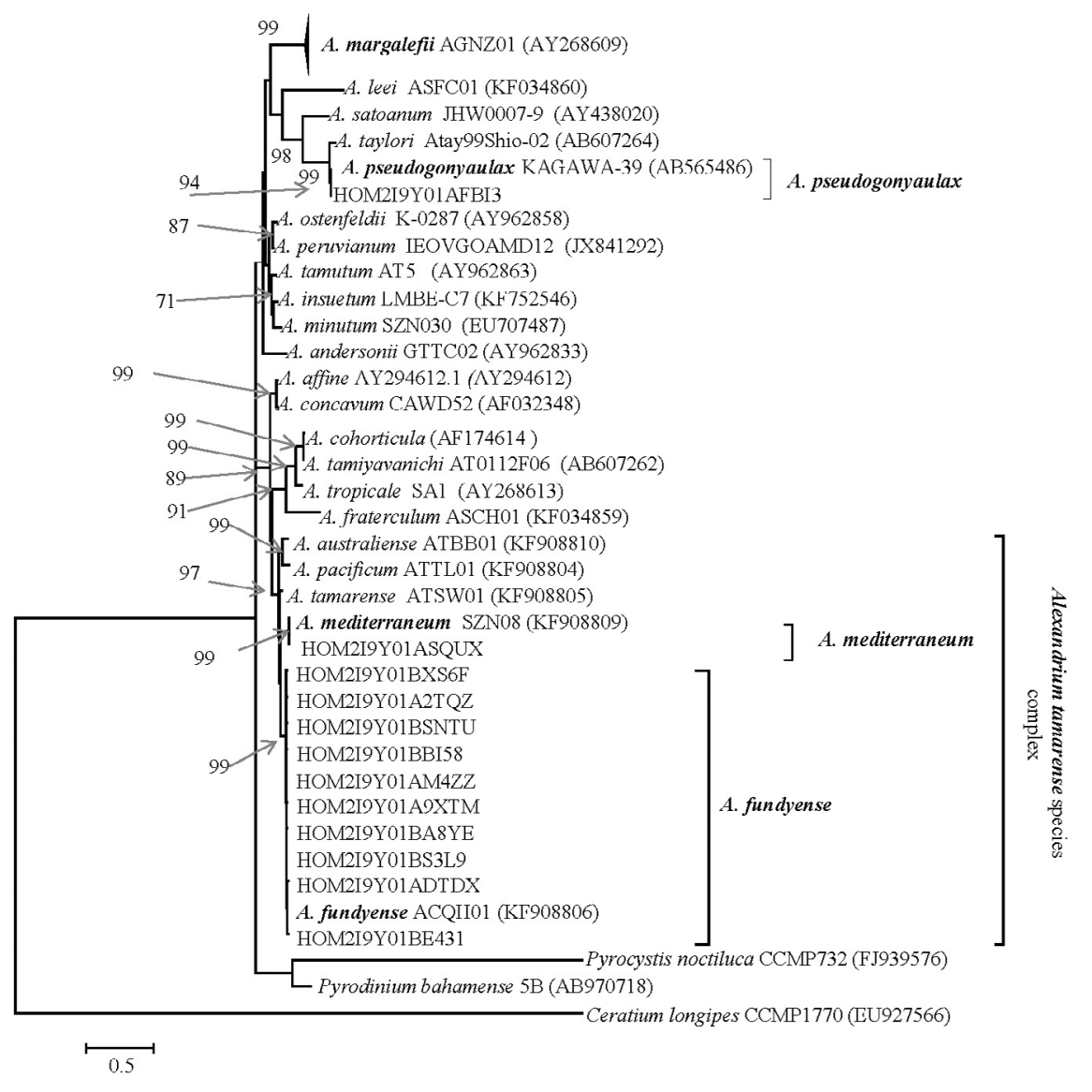

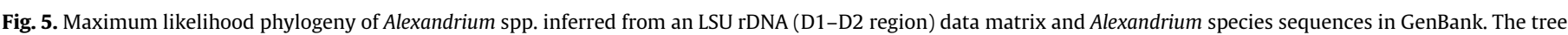

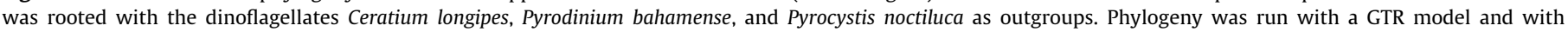
$1000 \times$ Bootstrap support, shown at the nodes of the tree.

geographical distribution in the Ebro Delta ecosystem. The majority of HAB taxa and phycotoxins found at the stations and their seasonal distribution in Ebro Delta embayments were consistent with usual events responsible for aquaculture harvesting closures in this region, such as occurrence of blooms of Dinophysis sacculus and Protoceratium reticulatum (FernándezTejedor et al., 2008). Significantly, samples containing higher cell abundances of $D$. sacculus and Dinophysis acuminata corresponded well to the occurrence of phycotoxins PTX-11, PTX-2, and its degradation product PTX-2sa (Miles et al., 2004), associated with these taxa (Fig. 4).

In some cases, incoherence between the appearance of particular phycotoxins and putative toxigenic organisms was evident in the current seasonal study. For example, YTX and cells of Protoceratium reticulatum, the putative YTX producer, were both detected from the same station on the same day, but not in samples from the same depth (information not shown in figures). Contributing to this uncertainty, the dinoflagellate Lingulodinium polyedrum, suspected as a source for YTX production in the Adriatic (Čustović et al., 2009), was also present in low amounts. Furthermore, there was no clear link between the distribution of likely toxigenic source organisms and the macrocyclic imine toxin SPX-1, elsewhere attributed to Alexandrium ostenfeldii (Cembella et al., 1999, 2000). This apparent lack of coherence between the presence of the toxin and the associated taxon also applied to GYM, usually produced by Karenia selliformis (Medhioub et al., 2009; Miles et al., 2003), or in brackish water by A. ostenfeldii (Harju et al., 2016; Van de Waal et al., 2015; Van Wagoner et al., 2011). High amounts of these toxins (Table 2) were detected in only one sample, and this simultaneous presence may indicate $A$. ostenfeldii as producer species of both toxins (Harju et al., 2016; Van de Waal et al., 2015; Van Wagoner et al., 2011). Yet, only few cells of Alexandrium spp. were detected by light microscopy on the respective day.

No PSP toxins were found in the plankton samples, despite the confirmed simultaneous presence of dinoflagellate species, including Alexandrium minutum and Alexandrium fundyense, known to produce these toxins albeit in low amounts in the northwest Mediterranean.

A chain-forming Gymnodinium species was morphologically characterized as either Gymnodinium catenatum or Gymnodinium

Table 2

Presence of phycotoxins ${ }^{\mathrm{a}}$ and maximum amounts [ $\mathrm{ng} \mathrm{L}^{-1}$ ] as found in Alfacs and Fangar bays during the study seasons in 2010 and 2011.

\begin{tabular}{|c|c|c|c|c|c|c|c|c|c|}
\hline & DA & DTX-2 & GYM & $\mathrm{OA}$ & PTX-2 & PTX-2sa & PTX-11 & SPX-1 & YTX \\
\hline Alfacs 2010 & & & 0.104 & & & & & 0.118 & \\
\hline Fangar 2010 & 18.8 & & 0.021 & & & & & 5.034 & \\
\hline Alfacs 2011 & & 4.956 & 39.931 & 3.735 & 4.528 & 1.035 & 0.531 & 184.418 & 1.110 \\
\hline Fangar 2011 & 4.1 & & & & 3.802 & 1.913 & & 4.888 & \\
\hline
\end{tabular}

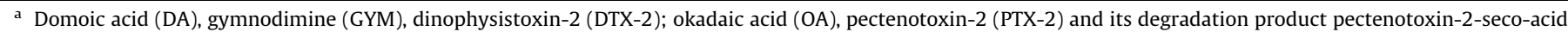
(PTX-2sa), pectenotoxin-11 (PTX-11), 13-demethyl spirolide C (SPX-1), and yessotoxin (YTX). 
Table 3

Minimum cell content of domoic acid (DA) associated with Pseudo-nitzschia spp. accumulations calculated by assuming that all Pseudo-nitzschia cells in each sample produce and contain an equal amount of toxin, and that DA is not leaked into the seawater or accumulated in grazers.

\begin{tabular}{|c|c|c|c|}
\hline & $\begin{array}{l}\mathrm{DA} \\
{\left[\mathrm{ng} \mathrm{L}^{-1}\right]}\end{array}$ & $\begin{array}{l}\text { Pseudo-nitzschia } \\
\text { spp. }\left[10^{6} \text { cells L }^{-1}\right]\end{array}$ & $\begin{array}{l}\text { DA } \\
{\left[\text { pg cell }^{-1}\right]}\end{array}$ \\
\hline Fangar Bay 2010, sample 1 & 3.6 & 0.42 & 0.009 \\
\hline Fangar Bay 2010, sample 2 & 4 & 0.43 & 0.009 \\
\hline Fangar Bay 2010, sample 3 & 18.8 & 0.07 & 0.269 \\
\hline Fangar Bay 2010, sample 4 & 12.4 & 0.07 & 0.178 \\
\hline Fangar Bay 2011, sample 1 & 4.1 & 6.90 & 0.001 \\
\hline Fangar Bay 2011, sample 2 & 3.2 & 0.15 & 0.021 \\
\hline
\end{tabular}

impudicum in Fangar Bay samples of 2011 by light microscopy. In another sample from the same bay, sequences consistent with $G$. catenatum were also detected by 454 sequencing, but this affiliation could not be confirmed by phylogenetic sequence analysis, because the identification was only weakly supported with statistics. Both methods brought, however, attention to the potential presence of the harmful species G. catenatum. This species is a known invader to the Mediterranean Sea, but can be easily confused with the non-toxic G. impudicum by light microscopy (Gómez, 2003).

There are several alternative but not mutually exclusive explanations for the apparent incoherence in the occurrence of these known toxigenic taxa and associated toxins. First, there may be novel and yet undescribed species as alternative sources for the detected toxins. Second, toxigenicity is known to vary widely even within described morphospecies (reviewed by Cembella, 2003). Moreover, the limitations of morphological identification by light microscopy are often apparent in plankton taxonomic analysis. For example, the only dinoflagellate species known to produce SPX-1, Alexandrium ostenfeldii, cannot be readily distinguished from certain other Alexandrium spp. by bright field light microscopy, and hence is frequently misidentified. Confirmation of the speciesdiagnostic characteristics requires more detailed analysis of thecal plate features beyond the scope of this study. Third, the issue of respective detection limits for taxon- and toxin-specific methods must be considered. In some cases, rare taxa in low cell abundance may be overlooked by microscopic analysis, yet the associated toxins may be detectible in bulk plankton samples. Conversely, weakly toxigenic taxa may be identified morphologically or by molecular genetic methods but the toxin yield may fall below the nominal toxin detection limit. Finally, grazing and cell degradation may yield morphologically unrecognizable taxa, while the toxins released are associated with other particulate and dissolved compartments, and nucleic acid fragments may remain intact for sequencing and species identity.

Recurrent fish kills in aquaculture and wild fauna in Alfacs Bay have been attributed to blooms of Karlodinium veneficum and Karlodinium armiger (Garcés et al., 2006). In contrast to frequent high cell abundances of Karlodinium spp. in Alfacs Bay (FernándezTejedor et al., 2010), high cell concentrations of this genus were detected in Fangar Bay for the first time in June 2010. These observations are consistent between the research sampling for this study (Busch et al., 2012) and the routine plankton monitoring program for shellfish safety (M. Fernández-Tejedor, unpublished). The presence of potentially ichthyotoxic Karlodinium species was confirmed by high-throughput pyrosequencing combined with phylogenetic assignment analyses of LSU rDNA sequences. A clear assignment to $K$. veneficum during increased abundances in Fangar Bay was weakly supported, while additional sequences could not be assigned at all. The second sequences could be indicative of a cooccurrence with $K$. armiger, which has been found before in the area (Garcés et al., 2006).
The fish-killing activity of Karlodinium veneficum is often assumed to be caused by the release of karlotoxins. The toxic potency of Karlodinium strains isolated from Alfacs Bay has been shown (Fernández-Tejedor et al., 2004, 2007), and recent research has revealed the occurrence of the karlotoxin analog KmTx-5 (B. Krock et al., unpublished observation) in cultured $K$. veneficum isolated from Fangar Bay in 2012. This analog has been previously reported from an isolate of $K$. veneficum from Plymouth, UK (Place et al., 2012). Given these observations, it is perhaps surprising that no known karlotoxins were detected by tandem mass spectrometry in any of the field samples from Alfacs or Fangar bays. This could be attributed to the relatively high detection limit for karlotoxins of this recently developed LC-MS/MS method, or to the presence of novel karlotoxin analogs with unknown ion masses.

No azaspiracids were detected in any Ebro Delta plankton samples during the study period. Since the discovery of Azadinium spp. as producer of azaspiracids (Tillmann et al., 2009), an ever increasing number of congeners have been found (Tillmann et al., 2016; Krock et al., 2015, 2012). The presence of azaspiracid analogs not surveyed in this analysis is therefore possible.

In any case, specimens of the dinoflagellate genus Azadinium, an identified source of these toxins (Tillmann et al., 2009), were encountered by light microscopy in several samples from both embayments. The genus was also putatively identified with 454 sequencing, as it was listed in MG-Rast with high percentage identity and high average alignment. The phylogenetic placement of the corresponding LSU sequences assigned the sequences to species (Azadinium spinosum and/or dalianense) but with only moderate to low support. The unresolved species designation is not surprising, considering that the number of newly described taxa of this recently erected genus is increasing rapidly (Tillmann et al., 2012, 2014), and the taxonomic affinities have not yet been fully established for the Mediterranean Sea. Species of Azadinium recorded from the Mediterranean Sea comprise Azadinium caudatum (references in Nézan et al., 2012) and the newly described species Azadinium dexteroporum, which is also capable of azaspiracid production (Percopo et al., 2013). High magnification light microscopy of Azadinium sp. in samples from Alfacs Bay showed the presence of an antapical spine and of multiple pyrenoids visible by a starch sheath (Fig. 3A, B). An antapical spine is also characteristic for $A z$. spinosum, Azadinium polongum, $A z$. caudatum, Azadinium trinitatum, Az. dalianense, and for the Mediterranean $A$. dexteroporum. The specimen depicted in Fig. 3 clearly differs from $A z$. dexteroporum $(<10 \mu \mathrm{m}$ in length and $<8 \mu \mathrm{m}$ in width; Percopo et al., 2013) by its larger size (ca. $16 \times 11 \mu \mathrm{m})$. In addition, the presence of multiple stalked pyrenoids is as yet known only for Azadinium poporum (Tillmann et al., 2011), but this species does not have an antapical spine. The presence of a spine and multiple pyrenoids in the episome is thus a unique combination of features and different from all species of Azadinium described so far. Cultured strains from the area are needed for more detailed morphological studies.

The identification of Chattonella marina by high-throughput 454 sequencing is consistent with the presence of a dense Chattonella bloom ( $3 \times 10^{6} \mathrm{~L}^{-1}$; Fernández-Tejedor, pers. comm.) during the sampling period. This resulted in discoloured patches on the water surface, which were observed in the time of sampling near the entrance to Fangar Bay in May 2011 (Busch, personal observation). If not present in such visible amounts, the identification of these raphidophytes in samples fixed with preservative reagents is hindered by distortion of their cell body.

The diatom genus Pseudo-nitzschia was present in high cell abundances during the study in both Alfacs and Fangar Bays and at various depths in the water column. Curiously, the associated toxin DA was detected only in plankton samples from Fangar Bay. Assuming that all measured DA is retained by producing 
Pseudo-nitzschia cells, and not leaked into the seawater medium or accumulated in grazers, and that all Pseudo-nitzschia taxa are toxigenic, it is possible to calculate a cell yield from total Pseudonitzschia abundances. This estimate of $0.27 \mathrm{pg}$ DA cell $^{-1}$ (Table 3 ) is obviously a minimum value given the assumptions, but is consistent with reports of other cellular DA concentrations from total abundances in field studies, e.g., Adams et al. (2000), even though much higher amounts have also been reported (see review of Lelong et al., 2012). This exceeds traces of 0.05 pg DA cell $^{-1}$ Pseudo-nitzschia spp. found in selected plankton samples during prior blooms in Alfacs and Fangar Bays (Fernández-Tejedor, unpublished results). These previous findings are based on analyses of integrated samples over the entire water column, which stresses the importance of depth resolved investigation for this thin-layer forming genus.

In the presented seasonal study, observations of different layers from surface to bottom revealed that DA-containing samples never corresponded to those with the highest Pseudo-nitzschia cell abundances in the respective cast (Fig. 4). In the few cases where Pseudo-nitzschia cell abundances reached bloom concentrations, estimated per cell toxin content was lowest (Table 3 ). These results indicate that the high-biomass dominant Pseudo-nitzschia taxa are not primarily responsible for DA production and shellfish contamination in the Ebro Delta area, although an association with high biomass Pseudo-nitzschia blooms cannot be ruled out. These findings are supported, however, by a study conducted in 2008-2011 along the Catalan coast, where DA was recorded in shellfish samples during all seasons and areas, and in all shellfish species sampled (Giménez Papiol et al., 2013). In that study, blooms of Pseudo-nitzschia spp. with the highest cell abundances did not correlate with levels of DA in shellfish, although persistent blooms of this genus above threshold alert cell numbers were present throughout the study period, and regulatory DA levels were exceeded in shellfish samples from Arenys de Mar in 2008 and Vilanova in 2010.

Notably, most DA-containing plankton occurred within the upper water column. This may lead to the assumption that environmental conditions such as light availability or stratification are favourable for toxin production or for the producer species. Variation in toxin production has been reported in response to various environmental factors for different Pseudo-nitzschia taxa, as a single component, or in combination, such as silicate and copper for Pseudo-nitzschia multiseries in New England (Fuentes and Wikfors, 2013), or for light or nutrients for Pseudo-nitzschia multistriata (Bates et al., 1998 in Lelong et al., 2012). Whereas Pseudo-nitzschia cell abundances are known to increase in late summer in the Ebro Delta embayments (Giménez Papiol et al., 2013), and the taxa Pseudo-nitzschia calliantha and Pseudo-nitzschia delicatissima have been associated with seasons and respective nutrient availability in the bays (Quijano-Scheggia et al., 2008), the only observations of DA in the field (Giménez Papiol et al., 2013) did not back this seasonal coherence. Observations of seasonal correspondences may, however, be impeded by variations in grazing pressure; recently, an induction of DA production by arctic Pseudo-nitzschia populations under the presence of copepods has been shown (Harðardóttir et al., 2015; Tammilehto et al., 2015). To shed light on toxin production in the field with respect to environmental factors in this region, detailed knowledge on the species-specific toxin production would be required.

Among the Pseudo-nitzschia taxa captured by qPCR assays, no single taxon could be assigned to all DA-containing samples, despite the systematic analysis of samples with a fine depthresolution to account for the tendency of Pseudo-nitzschia spp. to form thin layers in the water column. This study hints towards the presence of cryptic and yet unidentified taxa of the genus Pseudonitzschia in the Ebro Delta. First, a Pseudo-nitzschia taxon not yet included in regional studies, but related to the Pseudo-nitzschia delicatissima genotypic group was detected by qPCR. This taxon was sufficiently similar to $P$. delicatissima for the primers to match and amplify similarly, but it had sequence differences that altered its melt curve as compared to the control. Second, there were several occasions when high Pseudo-nitzschia cell abundances were confirmed by microscopy, and one of these samples contained DA, but none of the qPCR primers matched to the sequences in the corresponding samples (Fig. 4). It is, therefore, likely that the range of genetic diversity for this genus is not fully described in this area. In congruence with these findings, Pseudonitzschia cell abundances in Alfacs Bay derived by the same assays usually correlated well with genus-level cell counts during the regular monitoring program over a two year period from 2007 to 2009 , but did not match during a bloom in 2008, when abundances nearly reached $6 \times 10^{6}$ cells $\mathrm{L}^{-1}$ (Andree et al., 2011).

The advancement of molecular tools, in combination with morphotaxonomic methods, such as optical and electron microscopy (SEM/TEM) is crucial for the identification of the producers of DA in the region. The biogeographical specificity of the qPCR assays, while suffering from inherent exclusion of some non-target strains and or species, can also point towards the need for broadening the range of assays deployed on a regional basis (Andree et al., 2011) for the Ebro Delta embayments.

Phylogenetic analysis based upon 454 pyrosequencing of target genes is a highly valuable tool to address molecular diversity of the entire phytoplankton community, including HAB taxa, and to focus on potentially new harmful taxa for a region, such as Azadinium spp. or Gymodinium catenatum in the Ebro Delta. It is, however, necessary to conduct detailed bioinformatic investigations for the unambiguous identification of taxa by MG-Rast or other BLASTbased functions, and then perform phylogenetic analyses for confirmation of the species assignment. Even though some sequences may not be aligned with full statistical support in such subsequent analyses, as was the case for Azadinium sp. and $G$. catenatum in this study, phylogenetic sequencing aids to clarify which HAB taxa or groups not yet identified are present in a given aquaculture area and hence must eventually be addressed by classical taxonomy and by routine monitoring.

\section{Conclusions}

In addition to confirming associations of known harmful algal taxa with specific toxins for the Ebro Delta embayments, light microscopy and molecular phylogenetic analyses have provided new insights into the diversity and biogeography of certain HAB genera, particularly Alexandrium, Azadinium, Karlodinium, and Pseudo-nitzschia. Especially noteworthy is the record of Azadinium, as this genus had not been recorded previously for the Ebro Delta area, but may have high relevance for the aquaculture zone. The presence of significant amounts of DA in plankton samples, without apparent direct relationship with the cell abundance of dominant Pseudo-nitzschia species in the study season (end of spring-early summer), is a new finding of major importance, even though the culprit species could not be defined. The incorporation of molecular-based diversity methods was stressed by this study, especially for taxa which are not easily distinguishable by light microscopy, such as Pseudo-nitzschia species. Continued investigations on Pseudo-nitzschia species genetic diversity and detailed morphological analysis by SEM/TEM is highly appropriate for the region, particularly given the necessity to identify the toxin producer/s and bloom triggers for the Ebro Delta embayments. Findings from this assessment of HAB taxa and toxins in the Ebro Delta embayments underline the importance to screen for both usual and unexpected causal species of HAB events by alternative detection methods and with consideration of increasing resolution 
of spatio-temporal sampling regimes, particularly in aquaculture zones.

\section{Acknowledgments}

The authors acknowledge funding for field work by the Helmholtz POLMAR Graduate School, the Carl von Ossietzky University Oldenburg, and the IMARE GmbH. Support from the European Regional Development Fund (ERDF) funding the Institute of Marine Resources (IMARE) GmbH is also gratefully acknowledged. For assistance in field work we thank staff of the IRTA, AWI, IMARE, and HS Bremerhaven, especially technical support in the laboratory by Greta Reintjes and Nancy Kühne for high-throughput sequencing and Beatriz Noriega, Annegret Müller, and Wolfgang Drebing for toxin analysis. The IRTA monitoring is conducted within the project 'Monitoring of water quality in shellfish growing areas of the Catalan coast (DGPiAM-Generalitat de Catalunya)'. The project is within the framework of the SCOR/IOC GEOHAB Core Research Project on HABs in Fjords and Coastal Embayments.[SS]

\section{References}

Adams, N.G., Lesoing, M., Trainer, V.L., 2000. Environmental conditions associated with domoic acid in razor clams on the Washington coast. J. Shellfish Res. 19(2), 1007-1015.

Andree, K., Fernández-Tejedor, M., Elandaloussi, L.M., Quijano-Scheggia, S., Sampredo, N., Garcés, E., Camp, J., Diogéne, J., 2011. Quantitative PCR coupled with melt curve analysis for detection of selected Pseudo-nitzschia spp. (Bacillariophyceae) from the Northwestern Mediterranean Sea. Appl. Environ. Microb. 77 (5), 1651-1659.

Bates, S.S., Garrison, D.L., Horner, R.A., 1998. Bloom dynamics and physiology of domoic-acid-producing Pseudo-nitzschia species. In: Anderson, D.M., Cembella, A.D., Hallegraeff, G.M. (Eds.), Physiological Ecology of Harmful Algal Blooms. Springer Verlag, Heidelberg, pp. 267-292.

Busch, J.A., Cembella, A.D., Fernández-Tejedor, M., Diogéne, J., Zielinski, O., 2012. An integrated approach for the assessment of HAB dynamics in two NW Mediterranean bays from a GEOHAB perspective. In: Proceedings of the 14th International Conference on Harmful Algae, International Society for the Study of Harmful Algae and Intergovernmental Oceanographic Commission of UNESCO. pp. 84-86.

Cembella, A.D., 2003. Chemical ecology of eukaryotic microalgae in marine ecosystems. Phycologia 42 (4), 420-447.

Cembella, A.D., Lewis, N.I., Quilliam, M.A., 1999. Spirolide composition of microextracted pooled cells isolated from natural plankton assemblages and from cultures of the dinoflagellate Alexandrium ostenfeldii. Nat. Toxins 7 (5), 197-206.

Cembella, A.D., Lewis, N.I., Quilliam, M.A., 2000. The marine dinoflagellate Alexandrium ostenfeldii (Dinophyceae) as the causative organism of spirolide shellfish toxins. Phycologia 39 (1), 67-74.

CEN, 2006. Water quality-Guidance standard on the enumeration of phytoplankton using inverted microscopy (Utermöhl technique). BSI, p. 44.

Čustović, S., Orhanović, S., Ninčević-Gladan, Ž., Josipović, T., Pavela-Vrančič, M., 2009. Occurrence of yessotoxin (YTX) in the coastal waters of the Eastern-Mid Adriatic Sea (Croatia). Fresen. Environ. Bull. 18 (8), 1452-1455.

Diogène, J., Paz, B., Fernández-Tejedor, M., Mallat, E., Cañete, E., Caillaud, A., Elandaloussi, L.M., de la Iglesia, P., Cabado, A.G., Lago, J., Vieites, J., Franco, J., 2008. Evidencia de yessotoxinas en mejillón (Mytilus galloprovincialis) de la Bahía de Alfacs, Delta del Ebro, In: Gilabert, J. (Ed.), Actas IX Reunión Ibérica sobre Fitoplancton Tóxico y Biotoxinas, Cartagena, pp. 213-221.

Fawley, M.W., Fawley, K.P., 2004. A simple and rapid technique for the isolation of DNA from microalgae. J. Phycol. 40 (1), 223-225.

Fernández-Tejedor, M., Delgado, M., Garcés, E., Camp, J., Diogène, J., 2010. Toxic phytoplankton response to warming in two Mediterranean bays of the Ebro Delta, In: Briand, F. (Ed.), CIESM Workshop Monographs, Phytoplankton Response to Mediterranean Environmental Changes. No 40, Tunis, pp. 83-88.

Fernández-Tejedor, M., Delgado, M., Vila, M., Sampredo, N., Camp, J., Furones, M.D., Diogène, J., 2008. Resultados del programa de seguimiento de fitoplacton tóxico y biotoxinas en las zonas de producción de bivalvos de Cataluna: años 2003 3006 y primer trimestre del 2007, In: Gilabert, J. (Ed.), Avances y Tendencias en Fitoplankton Tóxico y Biotoxinas, Cartagena, pp. 37-46.

Fernández-Tejedor, M., Soubrier-Pedreño, M.Á., Furones, M.D., 2004. Acute LD50 of a Gyrodinium corsicum natural population for Sparus aurata and Dicentrarchus labrax. Harmful Algae 3 (1), 1-9.

Fernández-Tejedor, M., Soubrier-Pedreño, M.Á., Furones, M.D., 2007. Mitigation of lethal effects of Karlodinium veneficum and K. armiger on Sparus aurata: changes in haematocrit and plasma osmolality. Dis. Aquat. Org. 77, 53-59.

Fuentes, M.S., Wikfors, G.H., 2013. Control of domoic acid toxin expression in Pseudo-nitzschia multiseries by copper and silica: relevance to mussel aquaculture in New England (USA). Mar. Environ. Res. 83, 23-28.
Garcés, E., Fernández, M., Penna, A., Van Lenning, K., Gutierrez, A., Camp, J., Zapata, M., 2006. Characterization of NW Mediterranean Karlodinium spp. (Dinophyceae) strains using morphological, molecular, chemical, and physiological methodologies. J. Phycol. 42, 1096-1112.

Giménez Papiol, G., Casanova, A., Fernández-Tejedor, M., de la Iglesia, P., Diogène, J. 2013. Management of domoic acid monitoring in shellfish from the Catalan coast. Environ. Monit. Assess. 185 (8), 6653-6666.

Gómez, F., 2003. The toxic dinoflagellate Gymnodinium catenatum: an invader in the Mediterranean Sea. Acta Bot. Croat. 62 (2), 65-72.

Gu, H., Luo, Z., Krock, B., Witt, M., Tillmann, U., 2013. Morphology, phylogeny and azaspiracid profile of Azadinium poporum (Dinophyceae) from the China Sea Harmful Algae 21-22, 64-75.

Hallegraeff, G.M., 1993. A review of harmful algal blooms and their apparent global increase. Phycologia 32 (2), 79-99.

Harðardóttir, S., Pančić, M., Tammilehto, A., Krock, B., Møller, E., Nielsen, T. Lundholm, N., 2015. Dangerous relations in the arctic marine food web: interactions between toxin producing Pseudo-nitzschia diatoms and Calanus copepodites. Mar. Drugs 13 (6), 3809-3835

Harju, K., Koskela, H., Kremp, A., Suikkanen, S., de la Iglesia, P., Miles, C.O., Krock, B. Vanninen, P., 2016. Identification of gymnodimine D and presence of gymnodimine variants in the dinoflagellate Alexandrium ostenfeldii from the Baltic Sea. Toxicon 112, 68-76.

Hoppenrath, M., Elbrächter, M., Drebes, G., 2009. Marine Phytoplankton. Selected Microphytoplankton species from the North Sea around Helgoland and Sylt. Schweizerbart'sche Verlagsbuchhandlung, Stuttgart, Germany, pp. 264.

Krock, B., Seguel, C.G., Cembella, A.D., 2007. Toxin profile of Alexandrium catenella from the Chilean coast as determined by liquid chromatography with fluorescence detection and liquid chromatography coupled with tandem mass spectrometry. Harmful Algae 6 (5), 734-744.

Krock, B., Tillmann, U., Potvin, É., Jeong, H., Drebing, W., Kilcoyne, J., Al-Jorani, A. Twiner, M., Göthel, Q., Köck, M., 2015. Structure elucidation and in vitro toxicity of new azaspiracids isolated from the marine dinoflagellate Azadinium poporum. Mar. Drugs 13 (11), 6687-6702.

Krock, B., Tillmann, U., John, U., Cembella, A.D., 2008. LC-MS-MS aboard ship: tandem mass spectrometry in the search for phycotoxins and novel toxigenic plankton from the North Sea. Anal. Bioanal. Chem. 392, 797-803.

Krock, B., Tillmann, U., Voß, D., Koch, B.P., Salas, R., Witt, M., Potvin, É., Jeong, H.J., 2012. New azaspiracids in Amphidomataceae (Dinophyceae). Toxicon 60 (5), 830-839.

Lelong, A., Hégaret, H., Soudant, P., Bates, S.S., 2012. Pseudo-nitzschia (Bacillariophyceae) species, domoic acid and amnesic shellfish poisoning: revisiting previous paradigms. Phycologia 51 (2), 168-216.

Llebot, C., Solé, J., Delgado, M., Fernández-Tejedor, M., Camp, J., Estrada, M., 2011. Hydrographical forcing and phytoplankton variability in two semi-enclosed estuarine bays. J. Marine Syst. 86 (3-4), 69-86.

Medhioub, A., Medhioub, W., Amzil, Z., Sibat, M., Bardouil, M., Ben Neila, I., Mezghani, S., Hamza, A., Lassus, P., 2009. Influence of environmental parameters on Karenia selliformis toxin content in culture. Cah. Biol. Mar. 50 (4), 333 342.

Meyer, F., Paarmann, D., D’Souza, M., Olson, R., Glass, E., Kubal, M., Paczian, T. Rodriguez, A., Stevens, R., Wilke, A., Wilkening, J., Edwards, R., 2008. The metagenomics RAST server-a public resource for the automatic phylogenetic and functional analysis of metagenomes. BMC Bioinform. 9 (1), 386.

Miles, C.O., Wilkins, A.L., Munday, R., Dines, M.H., Hawkes, A.D., Briggs, L.R., Sandvik, M., Jensen, D.J., Cooney, J.M., Holland, P.T., Quilliam, M.A., Lincoln MacKenzie, A. Beuzenberg, V., Towers, N.R., 2004. Isolation of pectenotoxin-2 from Dinophysis acuta and its conversion to pectenotoxin- 2 seco acid, and preliminary assessment of their acute toxicities. Toxicon 43 (1), 1-9.

Miles, C.O., Wilkins, A.L., Stirling, D.J., MacKenzie, A.L., 2003. Gymnodimine C, an isomer of gymnodimine B, from Karenia selliformis. J. Agric. Food Chem. 51 (16), 4838-4840.

Moestrup, Ø., Akselman, R., Cronberg, G., Elbrächter, M., Fraga, S., Halim, Y., Hansen, G., Hoppenrath, M., Larsen, J., Lundholm, N., Nguyen, L.N., Zingone, A., 2009 onwards. IOC-UNESCO taxonomic reference list of harmful micro algae.

Nézan, E., Tillmann, U., Bilien, G.l., Boulben, S., Chèze, K., Zentz, F., Salas, R., Chomérat, N., 2012. Taxonomic revision of the dinoflagellate Amphidoma caudata: transfer to the genus Azadinium (Dinophyceae) and proposal of two varieties, based on morphological and molecular phylogenetic analyses. J. Phycol. 48 (4), 925-939.

Percopo, I., Siano, R., Rossi, R., Soprano, V., Sarno, D., Zingone, A., 2013. A new potentially toxic Azadinium species (Dinophyceae) from the Mediterranean Sea, A. dexteroporum sp. nov. J. Phycol. 49 (5), 950-966.

Pitcher, G.C., 2012. Harmful algae-the requirement for species-specific information. Harmful Algae 14, 1-4

Place, A.R., Bowers, H.A., Bachvaroff, T.R., Adolf, J.E., Deeds, J.R., Sheng, J., 2012 Karlodinium veneficum-the little dinoflagellate with a big bite. Harmful Algae 14, 179-195.

Quijano-Scheggia, S., Garcés, E., Flo, E., Fernández-Tejedor, M., Diogène, J., Camp, J. 2008. Bloom dynamics of the genus Pseudo-nitzschia (Bacillariophyceae) in two coastal bays (NW Mediterranean Sea). Sci. Mar. 72 (3), 577-590.

Ramón, M., Fernández, M., Galimany, E., 2007. Development of mussel (Mytilus galloprovincialis) seed from two different origins in a semi-enclosed Mediterranean Bay (N.E. Spain). Aquaculture 264 (1-4), 148-159.

Rines, J.E.B., Donaghay, P.L., Dekshenieks, M.M., Sullivan, J.M., Twardowski, M.S., 2002 Thin layers and camouflage: hidden Pseudo-nitzschia spp. (Bacillariophyceae) 
populations in a fjord in the San Juan Islands, Washington, USA. Mar. Ecol. Prog. Ser. 225, 123-137.

Scholin, C.A., Herzog, M., Sogin, M., Anderson, D.M., 1994. Identification of groupand strain-specific genetic markers for globally distributed Alexandrium (Dinophyceae). II. Sequence analysis of a fragment of the LSU rDNA gene. J. Phycol. 30 (6), 999-1011.

Tammilehto, A., Nielsen, T.G., Krock, B., Møller, E.F., Lundholm, N., 2015. Induction of domoic acid production in the toxic diatom Pseudo-nitzschia seriata by calanoid copepods. Aquat. Toxicol. 159, 52-61.

Tamura, K., Stecher, G., Peterson, D., Filipski, A., Kumar, S., 2013. MEGA6: molecular evolutionary genetics analysis version 6.0. Mol. Biol. Evol. 30 (12), 2725-2729.

Tillmann, U., Borel, C.M., Barrera, F., Lara, R., Krock, B., Almandoz, G.O., Witt, M. Trefault, N., 2016. Azadinium poporum from the Argentine continental shelf, Southwestern Atlantic, produces azaspiracid-2 and azaspiracid-2 phosphate. Harmful Algae 51, 40-55.

Tillmann, U., Elbrächter, M., John, U., Krock, B., 2011. A new non-toxic species in the dinoflagellate genus Azadinium: A. poporum sp. nov. Eur. J. Phycol. 46 (74-87)
Tillmann, U., Elbrächter, M., Krock, B., John, U., Cembella, A., 2009. Azadinium spinosum gen. et sp. nov. (Dinophyceae) identified as a primary producer of azaspiracid toxins. Eur. J. Phycol. 44 (1), 63-79.

Tillmann, U., Gottschling, M., Nézan, E., Krock, B., Billien, G., 2014. Morphological and molecular characterization of three new Azadinium species (Amphidomataceae, Dinophyceae) from the Irminger Sea. Protist 165, 417-444.

Tillmann, U., Soehner, S., Nézan, E., Krock, B., 2012. First record of the genus Azadinium (Dinophyceae) from the Shetland Islands, including the description of Azadinium polongum sp. nov. Harmful Algae 20, 142-155.

Tomas, C.R., 1997. In: Tomas, C.R. (Ed.), Identifying Marine Phytoplankton. Academic Press, San Diego, California, 858 pages.

Van de Waal, D.B., Tillmann, U., Martens, H., Krock, B., Van Scheppingen, Y., John, U., 2015. Characterization of multiple isolates from an Alexandrium ostenfeldii bloom in The Netherlands. Harmful Algae 49, 94-104.

Van Wagoner, R.M., Misner, I., Tomas, C.R., Wright, J.L.C., 2011. Occurrence of 12methylgymnodimine in a spirolide-producing dinoflagellate Alexandrium peruvianum and the biogenetic implications. Tetrahedron Lett. 52 (33), 4243-4246. 